Canadian Journal of Fisheries and Aquatic Sciences

Canadian Science Publishing

Journal canadien des sciences halieutiques et aquatiques

\title{
Environmental constraints on Didymosphenia geminata occurrence and bloom formation in Canadian Rocky Mountain lotic systems
}

\begin{tabular}{|r|l|}
\hline Journal: & Canadian Journal of Fisheries and Aquatic Sciences \\
\hline Manuscript ID & cjfas-2015-0361.R1 \\
\hline Manuscript Type: & Article \\
\hline Date Submitted by the Author: & 13-Nov-2015 \\
\hline Complete List of Authors: & $\begin{array}{l}\text { Jackson, Leland; University of Calgary } \\
\text { Corbett, Lisa; University of Calgary, } \\
\text { Scrimgeour, Garry; Parks Canada }\end{array}$ \\
\hline Keyword: & $\begin{array}{l}\text { ALGAE < Organisms, algal Stalk, diatom, <i>Didymosphenia } \\
\text { geminata</i>, INVASIVE SPECIES < Organisms }\end{array}$ \\
\hline \multicolumn{2}{|l}{} \\
\hline
\end{tabular}


1 Environmental constraints on Didymosphenia geminata occurrence and bloom formation in Canadian Rocky Mountain lotic systems

6 Leland J. Jackson ${ }^{1^{*}}$, Lisa Corbett ${ }^{1,2}$ and Garry Scrimgeour ${ }^{3,4}$

1. Ecology and Evolutionary Biology Research Cluster, Department of Biological Sciences,

$9 \quad$ University of Calgary, Calgary, Alberta, Canada

10 2. Program Development and Implementation, Glenbow Ranch Provincial Park Foundation,

11 Cochrane, Alberta, Canada and Program Leader at Weaselhead Preservation Society,

12 Calgary, Alberta, Canada.

13 3. Protected Areas Establishment and Conservation, Office of the Chief Ecosystem Scientist, 14 Parks Canada, Calgary, Alberta, Canada.

15 4. Adjunct Professor, Department of Biological Sciences, University of Alberta, Edmonton, 16 Alberta, Canada T6G2E9

$18{ }^{*}$ Correspondence: LJ Jackson, Department of Biological Sciences, University of Calgary, 2500

19 University Drive NW, Calgary, Alberta, Canada T2N 1N4

20 E-mail: ljackson@ucalgary.ca 


\section{Abstract}

23 The first documented bloom of Didymosphenia geminata in Alberta occurred in 2003 and

24 subsequent field investigations revealed that $D$. geminata was present in the periphyton of a

25 number of lotic systems, yet did not always form blooms. We sampled 76 sites in Canadian

26 Rocky Mountain National Parks, chosen to provide ranges in exposure to D. geminata

27 propagules and environmental conditions thought to affect $D$. geminata growth and bloom

28 formation. Generalized Linear Models were then used to determine environmental constraints on

29 habitat suitability and requirements for blooming and non-blooming populations across the

30 landscape. D. geminata was detected at $88 \%$ of sites and of those, $34 \%$ had blooms, defined as

31 visible mats of $D$. geminata stalks. D. geminata cell abundance was significantly negatively

32 related to stream velocity, stream order and TP concentration, yet there was no significant

33 relationship between $D$. geminata blooms and any of environmental variables measured. There

34 was a significant negative relationship between ash free dry mass (AFDM) and temperature when

35 cells were present but blooms absent, and a positive relationship between temperature and stalk

36 abundance when blooms were present. Total phosphorus, flow velocity and temperature were

37 significant environmental correlates of cell abundance, but we detected no thresholds related to

38 D. geminata blooms. The widespread occurrence of $D$. geminata over $1000 \mathrm{~s}$ of $\mathrm{km}^{2}$ and close

39 proximity of sites with and without blooms suggests that local, rather than regional factors drive

40 bloom development. 
44 Keywords: algae, algal stalk, diatom, Didymosphenia geminata, invasive species, nuisance

45 bloom, oligotrophic stream, periphyton.

\section{Introduction}

Aquatic system eutrophication typically results from excessive inputs of nitrogen and/or phosphorus (Nixon 1995; Schindler 1977; Biggs 2000; Dodds et al. 2002; Sunda et al. 2006).

49 Enhanced growth of algae can degrade water quality and change ecosystem structure-function relationships. Algal blooms can produce toxins or accumulate biomass that alters food web dynamics (Nielsen et al. 1990; Johansson and Graneli 1999a; Gobler et al. 2002). Large algal

52 blooms may alter habitat and trophic structure by depleting oxygen as algae decay (Grindley et al. 1964; Cho 1979; Mahoney and Steimle1979), reducing food and space for co-occurring organisms, destroying habitat and shading out submerged vegetation (Onuf 1994; 1996).

Blooms of Didymosphenia geminata (Lyngbye) Schmidt on Scandinavian river bottoms were reported a century ago (Lindstrom and Skulberg 2008) and have expanded globally over the last decade. The first reports of blooms in Western Canada occurred in 1989 on Vancouver Island (Sherbot and Bothwell 1993) and recently blooms have been identified in Rapid Creek,

59 South Dakota (Shearer and Erickson, 2006; Larson and Carreiro 2008), the Bow River, Alberta 60 (Kirkwood 2007; Bowman 2008), the Yukon River, Yukon (Barraclough 1995 cited in Bothwell

61 et al. 2009) the Kootenai River, Montana (Holderman and Hardy 2004), and Quebec (Simard and

62 Simoneau 2008), which led to the hypothesis of a rapid expansion of D. geminata to streams

63 throughout North America, potentially on anglers' felt soled waders (Bothwell et al. 2009).

64 However, as more data have been collected it appears more likely that D. geminata blooms are

65 driven by low phosphorus and other possible environmental drivers. D. geminata's first record in 66 the Kootenay area of British Columbia is from 1866, yet blooms in the Alberta portion of the 
67 Rocky Mountains were not noticed until the 1990s, with the spatial extent of blooms expanding 68 since then (Kirkwood et al. 2007; Bowman 2008).

69 Mitigation of many algal blooms involves nutrient input reductions. The frequency of

70 dividing D. geminata cells shows a positive relationship with dissolved phosphorus (Bothwell et

71 al. 2014), yet the amount of stalk material produced increases as dissolved phosphorus decreases

72 (Kirkwood et al. 2007; Bothwell and Spaulding 2008; Kilroy and Bothwell 2011). D. geminata

73 typically blooms in streams with low to undetectable phosphorus (Lindstrom and Skulberg 2008;

74 Kirkwood et al. 2009; Bothwell and Kilroy 2011) and ironically, D. geminata blooms are

75 indicative of pristine water quality (Sherbot and Bothwell 1993; Jonsson et al. 2000; Kirkwood et

76 al. 2007). D. geminata blooms in streams with low water velocity (Kilroy et al. 2005d; Larned et

77 al. 2006; Kirkwood et al. 2007; Tomas et al. 2010), regulated flows (Kirkwood et al. 2009), and

78 very cold water (Blanco and Ector 2002; Kirkwood et al. 2007; Lindstrom and Skulberg 2008).

79 In contrast to stalk production, cell presence has been linked to low base flow (Kumar et al.

80 2009) and maximum cell growth to high water velocity (Miller et al. 2009; Cullis et al. 2012).

81 D. geminata blooms are largely muccopolysaccharide stalk created during growth; large

82 blooms can completely homogenize streambeds (Larned et al. 2006; Spaulding and Elwell 2007).

83 The stalk is composed of long-lasting polysaccharides with apparently little nutritional value for

84 many benthic invertebrates (Larned et al. 2006; Larned et al. 2007; Spaulding and Elwell 2007).

85 Following invasion by $D$. geminata, changes in benthic invertebrate community composition

86 from dominance by Ephemeroptera, Plecoptera and Trichoptera to Diptera (Chironomidae,

87 Ceratopogonidae and Chaoboridae) have been found (Gillis and Chalifour 2010; James et al.

88 2010; Rost and Fritsen 2014). Alterations to benthic invertebrate community composition and 
89 sediment homogenization may affect the long-term growth and survival of fish populations

90 (Larned et al. 2006).

91 The goal of this research was to measure stream characteristics at 76 sites within Canadian

92 Rocky Mountain National Parks to identify relationships between site characteristics and $D$.

93 geminata cell abundance and bloom formation as a function of regional and local variables. Our

94 goal was to identify constraints on D. geminata distribution and abundance, and whether or not

95 environmental thresholds exist that distinguish blooming and non-blooming sites. If thresholds

96 are identified, such information could potentially be used to identify additional rivers and streams

97 at risk for D. geminata invasion or bloom development.

99 Methods

100

\section{Study sites}

102 The Canadian Rocky Mountain areas we sampled have geology dominated by shale, 103 sandstone, limestone and quartzite sedimentary material that formed a little less than ca. 0.5

104 billion years ago under ancient oceans. The areas of the Rocky Mountains we sampled were

105 formed and above water by ca. 75 million years ago.

106 Periphyton samples were collected during August and September, 2009, at 76 sites on

107 first to fifth order streams within National Parks of the Rocky Mountains of Alberta and British

108 Columbia (Figure 1). Streams are circumneutral to slightly alkaline $\mathrm{pH}$, moderate to high slope

109 and typically clear in late summer (water turbidity $<20 \mathrm{NTU}$ ). Concentrations of total

110 phosphorus (TP) and total nitrogen (TN) are typically very low (TP $<2$ to $10 \mu \mathrm{g} / \mathrm{L} ; \mathrm{TN}<50$ to

$111200 \mu \mathrm{g} / \mathrm{L})$. Streams are typically ice covered during November to April and open otherwise. 
112 Larger streams support rainbow trout (Oncorhynchus mykiss), bull trout (Salvelinus

113 confluentus) and mountain whitefish (Prosopium williamsoni) populations, which provide

114 angling opportunities. The sites experience a range of tourist and recreational activities,

115 including angling, and we chose sites to provide a range of stream order, stream type, substrate

116 type, area use, public access, algal community composition and nutrient concentrations following

117 identification by Parks Canada staff who are familiar with park usage and geography.

118 At each site, 13 environmental variables thought to potentially explain variation in the

119 occurrence and abundance of D. geminata were measured (Table 1). Variables were chosen to

120 represent variation at regional and local scales (Table 1).

Physico-chemical Attributes

Anthropogenic activity was evaluated as site use and angling pressure by Parks Canada

124 Agency staff familiar with each park. Site use was scaled one to five (one rarely used; five highly

125 frequented). Angling pressure was scored as frequent, occasional or rare. Mean water velocity

126 was calculated at 60\% water depth using a velocity meter (Global Water Flow Probe (FP111)).

127 Water temperature $\left(+/-0.1^{\circ} \mathrm{C}\right)$ was measured using a glass thermometer. Five stream widths and

128 depths were taken randomly at each site. Dissolved oxygen was measured with a YSI

129 Professional Plus dissolved oxygen meter. Triplicate water samples were taken at each site in

130 acid-washed, double-distilled water rinsed 1L Nalgene bottles. Bottles were completely filled

131 and stored on ice, prior to being sent to the Environment Canada Pacific and Yukon Laboratory

132 for Environmental Testing, in North Vancouver, British Columbia, for total phosphorus (TP) and

133 total nitrogen (TN) analyses. Soluble reactive phosphorus, total dissolved phosphorus and $\mathrm{NO}_{2}{ }^{-}$

134 were not measured as their concentrations are typically below detection limits in these systems. 
At each site, three cobbles $(0.05-0.1 \mathrm{~m})$ were chosen randomly within $0.5-2.5 \mathrm{~m}$ from

136 shore and 0.2-0.7 m water depth. Three $14.3 \mathrm{~cm}^{2}$ circles were traced on each cobble following a

137 PVC template and the algal material within the traced circle was mechanically dislodged from

138 the cobble with a combination of scalpels, tweezers and toothbrushes. The material from one

139 circle was placed in a $125 \mathrm{~mL}$ borosilicate bottle with some distilled water and Lugol's acid-

140 iodine fixative and stored in the dark. For enumeration, the entire sample was resuspended in

$141100 \mathrm{~mL}$ of water, then $10 \mathrm{~mL}$ sub-samples were poured into setting chambers for D. geminata

142 cell identification and enumeration using a Leica DM IRB inverted microscope (Leica

143 Microsystems, Wetzlar, Germany). Cells were counted at 100x magnification and identified by

144 multiple (2-5) stigmata positioned radially and symmetrically about one side of the central

145 nodule and the conspicuous size of $60-150 \mu \mathrm{m}$ length.

146 The material from the second circle was wrapped in aluminum foil, kept on ice during

147 transport to the lab, then stored at $-20^{\circ} \mathrm{C}$ until chlorophyll $a$ was extracted and quantified.

148 Samples were extracted into methanol and processed following Thompson et al. (1999), without

149 correction for phaeopigments. Chlorophyll $a$ was analyzed with a Spectromax Gemini XS dual-

150 scanning microplate spectrofluorometer (Molecular Devices, Sunnyvale, California USA) at an

151 excitation wavelength of $440 \mathrm{~nm}$ and emission wavelength of $665 \mathrm{~nm}$.

152 The material from the third circle was collected in a small plastic bottle and used for ash-

153 free dry mass (AFDM) determination. We use AFDM as a surrogate for the organic stalk content

154 of D. geminata sampled to distinguish this mass from the total dry mass, which would also

155 include Si from D. geminata frustules and any trapped inorganic particles. All AFDM samples

156 were processed according to Biggs and Kilroy (2000). 
158 Statistical Analyses

159 Descriptive statistics were calculated with Microsoft Excel (2011). Statistical analyses

160 were conducted using R (V2.8.1) (R development core team, 2008). Maps were traced by hand

161 from 1:250,000 topographic maps produced by the Canadian Centre for Mapping (Natural

162 Resources Canada). Any chemical concentrations that were undetectable were removed from

163 analyses. All hypothesis tests used a critical $\alpha=0.05$.

164 Spatial autocorrelation was assessed using a Mantel test. Generalized Linear Models

165 (GLM) and analyses of covariance (ANCOVA) were used to quantify relationships between

166 occurrence and abundance of $D$. geminata and selected environmental variables (Table 2) in two

167 ways. First, models of $D$. geminata occurrence or abundance and environmental variables from

168 the 76 sites were derived. Second, data from the 76 sites were used to identify relationships

169 between D. geminata bloom versus non-bloom sites and their corresponding environmental

170 matrices.

172 Generalized Linear Models (GLMs)

173 The 13-predictor variables were reduced to seven after correlations identified

174 multicollinearity between some variables. Seven predictor variables were then used to test $10 a$

175 priori models that represented multiple combinations of variables (Table 2). Environmental

176 variables were either measured during stream surveys (i.e. water velocity, water temperature, TP

177 and TN) or derived from queries of geographic information system (GIS) databases (latitude,

178 stream access and stream order). Elevation, stream depth and stream width were all correlated to

179 stream order $($ rho $=-0.34, p=0.0063$; rho $=0.63, p<0.001$; and, rho $=0.73, p<0.001$,

180 respectively). Site access and angling pressure (rho $=0.59, p=1.93 \times 10^{-8}$ ), dissolved oxygen and 
181 temperature $(r=-0.44, p<0.001)$ and latitude and stream type (rho $=0.26, p=0.025)$ were also

182 correlated. As a result, the final predictor variables were stream order, temperature, site access

183 and latitude, TP, TN and stream type.

GLMs were conducted on binary (D. geminata present or absent and D. geminata

185 blooming or non-blooming) and continuous (D. geminata abundance and AFDM) data and

186 environmental variables. Binomial, negative binomial and Gaussian error structures were

187 evaluated for best fit. AFDM was $\log (\mathrm{x}+1)$ transformed to reduce variance and over dispersion.

188 Akaike's Information Criterion corrected for small sample sizes (AICc) was used to

189 select the most parsimonious model (Burnham and Anderson 1998; Anderson et al. 2000). Each

190 model was evaluated by the difference in $\mathrm{AIC}_{\mathrm{c}}$ values from the most parsimonious model $\left(\Delta_{\mathrm{i}}\right)$,

191 which was weighted against other models. The top three models were selected but only models

192 that had a $\Delta_{\mathrm{i}}<10$ were considered statistically meaningful (Anderson et al. 2001). For all models

193 with variables that had Akaike's weights $\geq 0.01$, model averaged estimates of coefficients and

194 associated $p$-values were calculated to assess the variables' relative contributions to the variance

195 observed in D. geminata growth.

196 Because the GLMs indicated different responses of D. geminata cells and blooms to the

197 environmental variables, additional analyses were conducted to consider interactions between

198 sites where D. geminata bloomed and where D. geminata cells were present but did not bloom.

199 This analysis was conducted to evaluate relationships between environmental variables identified

200 as significant and their respective D. geminata bloom status. 


\section{Results}

203 Of the 76 sites sampled within the Alberta and British Columbian Rocky Mountain

204 National Parks, D. geminata was detected at $67(88 \%)$ sites, and of those 67 sites with $D$.

205 geminata cells, $23(34 \%)$ had D. geminata blooms (Figure 1). Blooms occurred along the Bow

206 River from the Bow Lake outflow and into the Banff town site. However within the Banff town

207 site, there were two sites with no blooms and one site where D. geminata was not detected

208 (Figure 1). In Waterton Lakes National Park there were two streams within the same tributary

209 that had differences in D. geminata abundance. There was no evidence of D. geminata blooms

210 along the heavily visited Red Rock Creek, but in a remote site along the Blakiston Creek a large

211 D. geminata bloom was observed (Figure 1).

212 Mantel tests revealed no spatial autocorrelation regarding where $D$. geminata cells were

213 present or absent $(p=0.37)$, where $D$. geminata blooms occurred $(p=0.11)$, or the amount of

$214 \operatorname{AFDM}(p=0.30)$. However, there was spatial autocorrelation to D. geminata cell abundance $(p=$ $2150.011)$

217 D. geminata cell presence and abundance

218 The most parsimonious model (Table 3) for D. geminata presence/absence included

219 stream order, water velocity, water temperature and TP. Although this model best fit the data, the

220 relationship was not statistically significant. D. geminata was found in streams that ranged in

221 order from one to five, water velocities that ranged from $0.11-1.36 \mathrm{~m} / \mathrm{s}$, temperatures that

222 ranged from $2.25-12.54{ }^{\circ} \mathrm{C}$ and TP concentrations that ranged from $<2.0-42 \mu \mathrm{g} / \mathrm{L}$.

Model averaging was only conducted on the presence or absence of $D$. geminata cells

224 model set as other model sets lacked appropriate Akaike's weights. The following ranking of the 
225 contribution of the main variables resulted for $D$. geminata presence/absence: latitude

$226($ coefficient $=-0.004, p=0.004)>\mathrm{TN}($ coefficient $=0.109, p=0.009)>$ velocity $($ coefficient $=$

$2270.48, p=0.074)>\mathrm{TP}($ coefficient $=11.97, p=0.088)>$ temperature $($ coefficient $=0.0149, p=$

228 0.396).

229 We found an effect of local variables on D. geminata cell abundance at a site (Table 3 ).

230 The most parsimonious model, based on AICc scores, revealed that D. geminata cell abundance

231 was significantly, negatively related to stream velocity, stream order and TP concentration (Table

232 3). The abundance of $D$. geminata cells was highest in stream orders 2 and 3, and lowest in

233 stream orders 5 and 6 (Figure 2). Higher D. geminata cell abundances were also found in low

234 water velocities and at low TP concentrations.

\section{D. geminata blooms and AFDM abundance}

The most parsimonious model, based on $\mathrm{AIC}_{\mathrm{c}}$ Scores, included stream order, water velocity, water temperature and TP (Table 3). Although this model best fit the data, there was no

239 significant relationship between the presence or absence of D. geminata blooms and any

240 measured environmental variables. D. geminata blooms were observed across a range of stream

241 orders (2 to 5$)$, water velocities $(0.17 \mathrm{~m} / \mathrm{s}$ to $0.76 \mathrm{~m} / \mathrm{s})$, temperatures $\left(3.7^{\circ} \mathrm{C}\right.$ to $\left.12.03{ }^{\circ} \mathrm{C}\right)$ and $\mathrm{TP}$

242 concentrations $(<2 \mu \mathrm{g} / \mathrm{L}$ to $8 \mu \mathrm{g} / \mathrm{L})$.

243 There was an effect of local variables on the amount of AFDM present at a site (Table 3).

244 The most parsimonious model, based on $\mathrm{AIC}_{\mathrm{c}}$ scores, revealed that the amount of AFDM was

245 significantly, positively related to temperature, and slightly negatively related to water velocity

246 (Table 3). 
248 Relationship between D. geminata bloom sites and non-bloom sites

Variables that had a significant relationship with $D$. geminata growth in the previous

250 subset of models were analyzed to identify differences between bloom sites and sites with $D$.

251 geminata cells and no blooms. There was a significant negative relationship between log TP

$252((\mu \mathrm{g} / \mathrm{L})+1)$ and $\log D$. geminata cells $\left(\left(\right.\right.$ cells $\left.\left./ \mathrm{cm}^{2}\right)+1\right)\left(Z_{3,31}=-3.407, p<0.001\right)$ in bloom and

253 non-bloom sites (Figure 3). D. geminata did not bloom if TP $>8 \mu \mathrm{g}$ TP/L, whereas D. geminata

254 cells in non-bloom sites occurred if TP $\geq 47 \mu \mathrm{g}$ TP/L. Unfortunately, TP was below analytical

255 detection $(2 \mu \mathrm{g} \mathrm{TP} / \mathrm{L})$ at 27 sites and these cases were excluded from analyses. We chose to

256 exclude such data, rather than use the analytical detection limit or 0.5 of the detection limit, to

257 maintain a conservative statistical approach. The message wouldn't change and indeed, increased

258 TP corresponded to lower D. geminata cell abundance wherever D. geminata occurred.

259 Blooms were present in streams with velocities that ranged from $0.162-0.712 \mathrm{~m} / \mathrm{s}$

260 (average velocity $0.46 \mathrm{~m} / \mathrm{s}$ ), while non-bloom sites ranged from $0.08-1.23 \mathrm{~m} / \mathrm{s}$ (average velocity

$2610.52 \mathrm{~m} / \mathrm{s}$. There was a significant negative relationship between $D$. geminata abundance and

262 stream velocity $\left(Z_{3,66}=-3.081, p=0.0021\right)$, but this relationship did not significantly differ

263 between bloom sites and non-bloom sites.

264 Stream temperature at all sites ranged from $2.4-15.2{ }^{\circ} \mathrm{C}$. There was a significant

265 positive relationship between AFDM and temperature at those sites with blooms present (Figure

$\left.2664 \mathrm{~A}-T_{3,64}=-2.05, p=0.044\right)$; however, the AFDM-temperature relationship was negative at

267 those sites where $D$. geminata was present but did not bloom $\left(T_{3,64}=2.204, p=0.031\right)$ (Figure

268 4B). Here we note that our characterization of 'non-blooming' refers to no stalks being present. 
270

271

272

273

274

275

276

277

278

279

280

281

282

283

284

285

286

\section{Discussion}

The presence of D. geminata cells at 67 of 76 sites, yet blooms at only 23 of these sites, indicates that $D$. geminata is widely distributed throughout the area sampled, but blooms at only a subset of sites. This observation is consistent with at least two possible hypotheses. First, there may be patchily distributed specific environmental conditions, such as low phosphorus (Bothwell and Kilroy 2011; Bothwell et al. 2014), relatively stable flows (Kawecka and Sanecki 2003; Noga 2003; Kirkwood et al. 2007; Bowman 2008) or a combination of these and other conditions that lead to bloom development at sites within the larger landscape. Second, there may be multiple strains of $D$. geminata, one or more of which is responsible for the blooms we first discovered in 2003 (Kirkwood et al. 2007) in southern Alberta, and a strain that does not bloom. We have not seen evidence that conclusively rejects a multiple strain hypothesis; however, growing evidence that draws on observations of spatial and temporal characteristics of blooms suggests that very low phosphorus is key to bloom formation (Taylor and Bothwell 2014) and bloom formation can be induced by dissolved phosphorus near or below analytical detection (Kilroy and Bothwell 2012; 2014). The occurrence of blooming and non-blooming populations in the same rivers, sometimes at adjacent sites, also suggests that blooms are driven by local, rather than regional factors, which is consistent with other findings (Bothwell et al. 2014).

When relations were explored between bloom and non-bloom sites and measured environmental variables a difference between temperature and AFDM was found. The fact that AFDM increases with temperature in bloom sites is consistent with temperature-dependent rates of metabolism to grow the stalk since most AFDM at these sites is D. geminata stalk. The very slightly negative relationship at non-bloom sites suggests that the periphyton community is not 
292 temperature controlled. Our measure of AFDM includes other diatoms, yet cursory

293 examination of the stalks via microscopy indicates that most organic material is D. geminata

294 stalks.

295

\section{D. geminata cell presence and abundance}

Our data indicate that most Alberta and British Columbia streams sampled support $D$.

geminata because it was found at $88 \%$ of sites sampled. Our sampling process used $3 \times 14.3 \mathrm{~cm}^{2}$

299 circular templates at each site to collect the periphyton matrix. Thus, if D. geminata is relatively

300 rare at some sites, we may not have detected it although it might be present - a finding that has

301 likely contributed to the idea that $D$. geminata's range has apparently expanded as the historic

302 range is poorly described. Models indicate that latitude and TN are important correlates of $D$.

303 geminata presence/absence. Historically, D. geminata was found at northern latitudes yet

304 recently its range has expanded (Spaulding and Elwell 2007; Blanco and Ector 2009). D.

305 geminata was historically found in low TN streams (Kirkwood et al. 2007; Schweiger et al.

306 2011) and can be limited by nitrogen availability (Larned et al. 2006), which is supported by our

307 data.

308 The significant negative relationship between D. geminata abundance and stream order is

309 consistent with Kilroy and Unwin (2011), who found that the New Zealand systems invaded by

310 D. geminata were strongly related to stream order. However, while they found most streams

311 invaded were stream order $>3$ and the occurrence of blooms increased with higher stream order,

312 we found that more cells occurred in lower stream orders. In New Zealand, D. geminata is

313 considered an invasive species. Low order streams may be visited less frequently and experience

314 fewer potential propagules than larger streams, and low order streams would require time for the 
315 diatom to move upstream from larger systems (Kilroy and Unwin, 2011). In the systems we

316 sampled, D. geminata may be native and cells may persist better in lower order streams and

317 passively flow to higher order streams.

318 The most parsimonious GLM indicated that lower water velocities and lower TP

319 concentrations were associated with higher D. geminata abundances, consistent with Kilroy et al.

320 (2005), Larned et al. (2006), Kirkwood et al. (2007) and Tomas et al. (2010), and who have

321 correlated D. geminata abundance with lower, stabilized flows. The negative relationship

322 between $D$. geminata cell abundance and TP concentration is also consistent with previous

323 studies that found D. geminata in oligotrophic systems (Bowman et al. 2007; Kirkwood et al.

324 2009). Kilroy and Bothwell (2012) demonstrated that ambient dissolved reactive phosphorus

325 concentrations trigger a switch in $D$. geminata colony growth such that below $2 \mu \mathrm{g} / \mathrm{L}$ cell

326 division slows and stalk growth commences, which is a challenge for all field surveys since this

327 puts the dissolved phosphorus threshold at the analytical detection limits. Others, (e.g.,

328 Lindstrom and Skulberg 2008; Khan-Bureau et al. 2014) have found a somewhat higher

329 threshold for DP than those reported by Kilroy and Bothwell (2012). Thus at high TP, D.

330 geminata can exist, does not appear to form blooms and cell density is negatively related to

331 temperature while at low phosphorus cell division slows and stalks form, perhaps to acquire

332 phosphorus from an alternate source, and stalk production is positively related to temperature.

333 The stalk formation - P relationship is consistent with $\mathrm{P}$ being used to reduce $D$. geminata

334 blooms (James et al. 2015). Finally, D. geminata stalks can contain alkaline phosphatase

335 (Elwood and Whitton 2007), which presumably allows some use of organic P as a P substrate. 


\section{D. geminata bloom presence and AFDM abundance}

The most parsimonious GLM indicated that regional (order) and local (water velocity, water temperature and TP) variables were related to D. geminata bloom occurrence. However, none of these variables were identified as significant effects.

The most parsimonious GLM revealed that stream order, water velocity, water temperature and TP are related to the AFDM measured at a site. However stream order and TP do not have a significant effect on the AFDM. There was a statistically significantly negative relationship between water temperature and AFDM and a slight negative relationship between AFDM and stream velocity.

AFDM was inversely related to stream velocity and we found no D. geminata blooms at velocities above $0.8 \mathrm{~m} / \mathrm{s}$ at the time of sampling. Flow velocity (Kilroy et al. 2005; Larned et al. 2006; Kirkwood et al. 2007; Tomas et al. 2010) and flow stability (Kirkwood et al. 2009) have been correlated with $D$. geminata blooms.

We found that AFDM was significantly, inversely related to water temperature across all sites. However, we also found a negative relationship between AFDM and temperature where no D. geminata blooms were observed and a significant positive relationship between AFDM and temperature where D. geminata bloomed, up to a maximum temperature of $14^{\circ} \mathrm{C}$. Sundareshwar et al. (2011) suggested that when D. geminata mats form, a positive feedback is established because stalk material can absorb Fe and P, which can facilitate further cell growth. Because we sampled streams in late summer at low flow, temperatures measured were at, or close to, annual maxima. Thus, there might be a temperature threshold around $14^{\circ} \mathrm{C}$ in these systems or temperature may be correlated to an environmental driver we did not measure. Kilroy et al. (2006) noted that blooms appeared to be restricted to locations where the lowest winter air 
360 temperatures were below $5^{\circ} \mathrm{C}$. D. geminata is characterized as a cold water species (Kirkwood

361 et al. 2007; Lindstrom and Skulberg 2008; Blanco and Ector 2009) although it can persist in

362 water up to $23^{\circ} \mathrm{C}$ and rarely is in its vegetative state above $18^{\circ} \mathrm{C}$ (Lindstrom and Skulberg 2008).

363 Recent reports of blooms appearing in warmer water (Spaulding and Elwell 2007; Kumar et al.

364 2009) might indicate that there may be more susceptible rivers and continued D. geminata range

365 expansion, possibly because $D$. geminata can alter its phenotype when exposed to different

366 temperatures. Despite remaining uncertainty regarding a possible genetic basis for temperature

367 adaptation or plasticity of one original strain, we have shown that D. geminata was widespread

368 throughout the seven Canadian National Parks we sampled, that drivers of blooms vary over

369 relatively small spatial scales, and that blooms are associated with very low to undetectable total

370 phosphorous concentrations.

371

372 Acknowledgements

373 This work was financially supported by the Natural Sciences and Engineering Research

374 Council of Canada, Parks Canada Agency and the Alberta Conservation Association. We thank

375 Shelley Humphries, Ward Hughson, Barb Johnston, Charlie Pacas, Danielle Bachman, Lisa

376 Larson, Sarah Boyle, Heidi Fengler, Carol Doering, Dan Rafla, Alicia Fontaine, Stephanie

377 Crowshoe, Jon Stuart-Smith, Sean LeMoine, Queenie Gray, Randall Schwanke and Cal Syme for

378 providing access and help sampling the National Parks.

379

$380 \quad$ References

381 Anderson, D.R., Link, W.A., Johnson D.K. and Burnham, K.P. 2001. Suggestions for presenting 382 the results of data analysis. J. Wildlife Manage. 65: 373-378. doi: $10.2307 / 3803088$ 
383

384

385

386

387

388

389

390

391

392

393

394

395

396

397

398

399

400

401

402

403

Anderson, D.R., Burnham, K.P and Thompson, W.I. 2000. Null hypothesis testing: problems, prevalence, and an alternative. J. Wildlife Manage. 64: 912-923. doi: 10.2307/3803199

Barraclough, C.L. 1995. Periphyton of the Yukon River (1992): presence of Didymosphenia geminata (Lyngb.) M. Schm. Unpublished report, Department of Biology, University of Victoria. 11p. In Bothwell, M.L., Donovan, R.L., Wright, H. \& Deniseger, J. 2009. On the boots of fishermen: The history of Didymo blooms on Vancouver Island, British Columbia. Fisheries. 24: 382-388. doi:10.1577/1548-8466-34.8.382

Biggs, B.J.F. 1996. Hydraulic habitat of plants in streams. Regul. River. 12: 131-144. doi: 10.1002/(SICI)1099-1646 (199603)12:2/3\%3C131::AID-RRR385\%3E3.0.CO;2-X

Biggs, B.J.F. 2000. Eutrophication of streams and rivers: dissolved nutrient-chlorophyll relationships for benthic algae. J. N. Am. Benthol. Soc. 19: 17-31. doi:10.2307/1468279

Blanco, S. and Ector, L. 2009. Distribution, ecology and nuisance effects of the freshwater invasive diatom Didymosphenia geminata (Lyngbye) M. Schmidt: a literature review. Nova Hegwigia, 88: 347-422. doi:10.1127/0029-5035/2009/0088-0347

Bothwell, M.L. and Spaulding, S.A. 2008. Synopsis of the 2007 International Workshop on Didymosphenia geminata. In Bothwell, M.L. \& Spaulding, S.A. eds. Proceedings of the International Workshop on Didymosphenia geminata, Montreal, Quebec. Can. Tech. Rep. Fish. Aquat. Sci. 2795, xiii-xxxi.

Bothwell, M.L., Lynch, D.R., Wright, H. and Deniseger, J. 2009. On the Boots of Fishermen, The history of Didymo blooms on Vancouver Island, British Columbia. Fisheries 24: 382388. doi:10.1577/1548-8466-34.8.382 
404 Bothwell, M.L. and Kilroy, C. 2011. Phosphorus limitation of the freshwater benthic diatom 405 Didymosphenia geminata determined by the frequency of dividing cells. Freshwater Biol. 56: 565-578. doi: 10.1111/j.1365-2427.2010.02524.x

407 Bothwell, M.L., Taylor, B.W. and Kilroy C. 2014. The Didymo story: the role of low dissolved phosphorus in the formation of Didymosphenia geminata blooms. Diatom Res. 29: 229-236. doi: 10.1080/0269249x.2014.889041

Bowman, M.F. 2008. Increased Didymosphenia geminata biomass in response to low-level phosphorous enrichment of oligotrophic rivers. In Bothwell, M.L. and Spaulding, S.A. eds. information-theoretic approach. Springer-Verlag, New York, USA.

416 Cho, C.H. 1979. Mass mortalities of oyster due to red tide in Jinhae Bay in 1978. Bulletin of Korean Fisheries Society, 12: 27-33.

418 Cullis, J.D.S., Gillis, C-A., Bothwell, M.L., Kilroy, C., Packman, A. and Hassan, M. 2012. A 419 conceptual model for the blooming behavior and persistence of the benthic mat-forming 420 diatom Didymosphenia geminata in oligotrophic streams. J. Geophy. Res. 117: G00N03. 421 doi: $10.1029 / 2011 J G 001891$.

422 Dodds, W.K., Smith, V.H. and Lohman, K. 2002. Nitrogen and phosphorus relationships to 423 benthic algal biomass in temperate streams. Can. J. Fish. Aquat. Sci. 59: 865-874. doi:10.1139/f02-063 
425 Elwood, N.T.W. and Whitton, B.A. 2007. Importance of organic phosphate hydrolyzed in 426 stalks of the lotic diatom Didymosphenia geminata and the possible impact of atmospheric and climatic changes. Hydrobiologia 592: 121-133. doi:10.1007/s10750-007-0728-0

428 Gillis, C-A. and Chalifour, M. 2010. Changes in the macrobenthic community structure following the introduction of the invasive algae Didymosphenia geminata in the Matapedia River (Québec, Canada). Hydrobiologia 647: 63-70. doi: 10.1007/s10750-009-9832-7

Gobler, C.J., Renaghan, M.J. and Buck, N.J. 2002. Impacts of nutrients and grazing mortality on the abundance of Aureococcus anophagefferens during New York brown tide bloom.

Grindley, J.R., Taylor, J.R. and Day, J.H. 1964. Red water and marine fauna mortality near Cape Town. Trans. Roy. Soc. S. Afr. 37: 111-130. doi:10.1080/00359196409519061

Holderman, C.E. and Hardy, R. 2004. Kootenai River Ecosystem Project: an ecosystem approach to evaluate and rehabilitate a degraded, large riverine ecosystem. Final Report to Bonneville

James, D.A., Ranney, S.H., Chipps, S.R. and Spindler, B.D. 2010. Invertebrate composition and Power Administration, Portland OR. Project 1994-049-00, Contract 00004029. abundance associated with Didymosphenia geminata in a montane stream. J. Freshwater Ecol. 25: 235-241. doi: 10.1080/02705060.2010.9665073

James, D.A., Bothwell, M.L., Chipps, S.R. and Carreiro, J. 2015. Use of phosphorus to reduce blooms of Didymosphenia geminata in an oligotrophic stream. Freshwater Science 34: in press. doi:10.1068/683038

Johansson, N. and Graneli, E. 1999. Cell density, chemical composition and toxicity of Chrysochromulina polylepis (Haptophyta) in relation to different N:P supply ratios. Mar. Biol. 125: 209-217. doi:10.1007/s002270050618 
448 Jonsson, G.S., Jonsson I.R., Bjornsson, M. and Einarsson, S.M. 2000. Using regionalization in 449 mapping the distribution of the diatom species Didymosphenia geminata (Lyngbye) M. 450 Schmidt in Icelandic rivers. Verh. Internat. Verein. Theor. Angew. Limnol. 27: 340-343. 451 Kawecka, B. and Sanecki, J. 2003. Didymosphenia geminata in running waters of Southern 452 Poland-symptoms of change in water quality? Hydrobiologia 495: 193-201. doi: 10.1023/A:1025469500265

454 Kilroy, C., Snelder, T. and Sykes, J. 2005. Likely environments in which the nonindigenous 455 freshwater diatom can survive, in New Zealand: National Institute of Water and 456 Didymosphenia geminata in New Zealand. Aquatic Invasions 6: 249-262. doi:10.3391/ai.2011.6.3.02

Kilroy, C. and Bothwell, M.L. 2011. Environmental control of stalk length in the bloom-forming

Kilroy, C. and Bothwell, M.L. 2012. Didymosphenia geminata growth rates and bloom formation in relation to ambient dissolved phosphorus concentration. Freshwater Biol. 57: 641-653.

Kilroy, C. and Bothwell, M.L. 2014. Attachment and short-term stalk development of Didymosphenia geminata: effects of light, temperature and nutrients. Diatom Res. 29: 237248.

Kirkwood, A.E., Shea, T., Jackson, L.J. and McCauley, E. 2007. Didymosphenia geminata in two Alberta headwater rivers and emerging invasive species that challenges conventional 
471

472

\section{3}

474

475

476

477

478

views on algal bloom development. Can. J. Fish. Aquat. Sci. 64: 1703-1709.

$$
\text { doi:10.1139/f07-152 }
$$

Kirkwood, A.E., Jackson, L.J. and McCauley, E. 2009. Are dams hotspots for Didymosphenia geminata blooms? Freshw. Biol. 54: 1856-1863. doi:10.1111/j.1365-2427.2009.02231.x

Kumar, S., Spaulding, S.A., Stohlgren, T.J., Hermann, K., Schmidt, T. and Bahls, T.J. 2009. Potential habitat distribution for freshwater diatom Didymosphenia geminata in the continental United States. Front. Ecol. Environ. 7: 415-420. doi: 10.1890/080054

Larson, A.M. and Carreiro, J. 2008. Relationship between nuisance blooms of Didymosphenia geminata and measures of aquatic community composition in Rapid Creek, South Dakota. 45-49. In Bothwell, M.L. and S.A. Spaulding. eds. Proceedings of International workshop on Didymosphnia geminata. Montreal, Quebec. Can. Tech. Rep. Fish. Aquat. Sci. 2795.

Larned S., Biggs, B., Blair, N., Burns, C., Jarvie, B., Jellyman, D., Kilroy, C., Leathwick, J., Lister, K. Nagels, J., Schallenberg, M., Sutherland, S., Sykes, J., Thompson, W., Vopel, K., and Wilcock, B. 2006. Ecology of Didymosphenia geminata in New Zealand-Habitat and ecosystem effects-Phase 2: National Institute of Water and Atmospheric Research, New Zealand, Client Report CHC2006-086, NIWA Project MAF06507, Christchurch, New Zealand.

Larned, S., Arscott, D., Blair, N., Jarvie, B., Jellyman, D., Lister, K., Schallenberg, M., Sutherland, S., Vopel, K., and Wilcock, B. 2007. Ecological studies of Didymosphenia geminata In New Zealand, 2006-2007. National Institute of Water and Atmospheric Research. Client Report: CHC2007-050 Christchurch, New Zealand.

Lindstrom, E. A. and Skulberg, O.M. 2008. Didymosphenia geminata - a native diatom species of Norwegian rivers coexisting with the Atlantic salmon. In Bothwell, M.L. \& Spaulding, 
S.A., eds. Proceedings of the 2007 International Workshop on Didymosphenia geminata, Montreal, Quebec. Can. Tech. Rep. Fish. Aquat. Sci.: 2795: 35-40.

Mahoney, J.B. and Steimle Jr., F.W. 1979. A mass mortality of marine animals associated with a bloom of Certum triposin in the New York Bight. Toxic dinoflagellate blooms (ed. by Taylor, D.L \& Seliger, H.H.), pp. 225-230. Elsevier/North Holland, New York, U.S.A.

Miller, M.P., McKnight, D.M., Cullis, J.D., Greene, A., Vietti, K. and Liptzin, D. 2009. Factors controlling streambed coverage of Didymosphenia geminata in two regulated streams in the Colorado front range. Hydrobiologia 630: 207-218. doi: 10.1007/s10750-009-9793-x.

Nielsen, T.G., Kioerboe, T. and Bjoersnsen, P.K. 1990. Effects of a Chrysochromulina polylepis subsurface bloom on the planktonic community. Mar. Ecol. Prog. Ser. 62: 21-35. doi:10.3354/meps062021

Nixon, S.W. 1995. Coastal marine eutrophication: a definition, social causes, and future concerns. Ophelia 41: 199-219. doi:10.1080/00785236.1995.10422044

Noga, T. 2003. Dispersion of Didymosphenia geminata in the flowing waters of Southern Poland-new sites of species occurrence in the Orawska Watershed and the Orawska basin. Oceanol. Hydrobiol. St. 32: 159-170.

Onuf, C.P. 1996. Seagrass responses to long-term light reduction by brown tide in upper Laguna Madre, Texas: distribution and biomass patterns. Mar. Ecol. Prog. Ser. 138: 219-231. doi:10.3354/meps138219

Onuf, C.P. 1994. Seagrasses, dredging and light in Laguna Madre, Texas, U.S.A. Estuar. Coast. Shelf Sci. 39: 75-91. doi:10.1006/ecss.1994.1050

R Development Core Team. 2008. R: A language and environment for statistical computing. $\mathrm{R}$ Foundation for Statistical Computing, Vienna, Austria. http://www.R-project.org. 
517 Rost, A.L. and Fritsen, C.H. 2014. Influence of a tributary stream on benthic communities in a

518 Didymosphenia geminata impacted stream in the Sierra Nevada, USA. Diatom Res. 29: 249-

519 257. doi: 10.1080/0269249X.2014.929029

520 Schindler, D.W. 1977. Evolution of phosphorus limitation in lakes. Science 195: 260-262.

521 doi:10.1126/science.195.4275.260

522 Schweiger, E.W., Ashton, I.W., Mohlfeld C.C., Jones, L.A. and Bahls, L.L. 2011. The

523 distribution and abundance of a nuisance native alga, Didymosphenia geminata, in streams

524 of Glacier National Park: Climate drivers and management implications. Park Science 28:

$525 \quad 88-91$.

526 Shearer, J. and Erickson, J. 2006. Didymosphenia geminata and the Rapid Creek brown trout

527 fishery, South Dakota. In American Fisheries Society Western Division Meeting, 15-16 May,

528 2006, Montana State University, Montana. Current knowledge of Didymosphenia geminata:

529 developing a research and management response. Coordinated by S. Spaulding, R. Wiltshire,

530 and L. Elwell. American Fisheries Society, Bozeman, Mont. USA. In Bothwell, M.L.,

531 Lynch, D.R., Wright, H. \& Reniseger, J. 2009. On the Boots of Fishermen, The history of

532 Didymo blooms on Vancouver Island, British Columbia. Fisheries 24: 382-388.

533 doi:10.1577/1548-8466-34.8.382

534 Sherbot, D.M.J. and Bothwell, M.L. 1993. Didymosphenia geminata (Gomphonemaceae). A

535 review of the ecology of D. geminata and the physiochemical characteristics of endemic

536 catchments on Vancouver Island. NHRI Contribution 93005. National Hydrology Research

537 Institute, Environment Canada, Saskatoon, Saskatchewan. 66 pp.

538 Shundareshwar, P.V., Upadhayay, S., Abessa, M., Honomuchl, S., Berdanier, B., Spaulding S.A.,

539 Sandvik, C. and Trennepohl, A. 2011. Didymosphenia geminata: Algal blooms in 
$540 \quad$ oligotrophic streams and rivers. Geophysical Research Letters 38, L10405. doi:

$541 \quad 10.1029 / 2010 G L 046599$.

542 Simard, I. and Simoneau, M. 2008. Didymo dans les rivières du Québec: état de situation. In

543 M.L. Bothwell and S.A. Spaulding, eds. Proceedings of the 2007 International Workshop on

544 Didymosphenia geminata, Montreal, Quebec. Can. Tech. Rep. Fish. Aquat. Sci. 2795: 3-5.

545 Spaulding, S.A. and Elwell, L. 2007. Increase in nuisance blooms and geographic expansion of

546 the freshwater diatom Didymosphenia geminata: recommendations for response. USGS

$547 \quad$ Open File Report 2007-1425.

548 Sunda, W.G., Graneli, E. and Gobler, C.J. 2006. Positive feedback and the development and

549 persistence of ecosystem disruptive algal blooms. J. Phycol. 42: 963-974.

$550 \quad$ doi: $10.1111 / \mathrm{j} .1529-8817.2006 .00261 . x$

551 Taylor, W.D. and Bothwell, M.L. 2015. The origin of invasive microorganisms matter for

552 science, policy, and management : the case of Didymosphenia geminata. BioScience 64 :

$553 \quad$ 531-538. doi:10.1093/biosci/biu060

554 Tomas, P., Oscos, J., Duran, C., Fernandez, D. and Marin, J.P. 2010. Distribution of the bloom

555 forming diatom Didymosphenia geminata in the Ebro River Basin (Northeast Spain) in the

556 period 2006-2009. Aquatic Invasions 5: 285-289. doi:10.1111/j.1529-8817.2006.00261.x 


\section{List of Tables}

558

Table 1. Environmental variables used to predict the occurrence and abundance of D. geminata at 76 sites within Alberta and British Columbia Rocky Mountain National Parks sampled during summer, 2009.

\begin{tabular}{|c|c|c|c|}
\hline Variable & Abbreviation & Units & Range \\
\hline \multicolumn{4}{|l|}{ Regional Variables } \\
\hline Elevation & Elev & $\mathrm{m}$ & $576-2449$ \\
\hline Latitude* & Lat & $\circ$ & $\begin{array}{l}-118.45- \\
-113.68\end{array}$ \\
\hline Stream Order* & Order & dimensionless & $1-6$ \\
\hline Stream Type & Type & dimensionless & $\begin{array}{l}\text { fast / slow } \\
\text { riffle, fast/slow } \\
\text { run, pool or } \\
\text { cascade }\end{array}$ \\
\hline \multicolumn{4}{|l|}{ Local Variables } \\
\hline Water Velocity* & Velocity & $\mathrm{m} / \mathrm{s}$ & $0.08-1.23$ \\
\hline Total Nitrogen* & $\mathrm{TN}$ & $\mathrm{mg} / \mathrm{L}$ & $\begin{array}{l}0.01 \text { (min. } \\
\text { detection) - } \\
0.26\end{array}$ \\
\hline Total Phosphorus* & $\mathrm{TP}$ & $\mathrm{mg} / \mathrm{L}$ & $\begin{array}{l}0.002(\mathrm{~min} . \\
\text { detection })- \\
0.047\end{array}$ \\
\hline Water Temperature* & Temp & ${ }^{\circ} \mathrm{C}$ & $2.25-18.2$ \\
\hline Dissolved Oxygen & DO & $\mathrm{mg} / \mathrm{L}$ & $0.75-14.19$ \\
\hline Stream Depth & Depth & $\mathrm{m}$ & $0.046-1.46$ \\
\hline Stream Width & Depth & $\mathrm{m}$ & $0.56-121.33$ \\
\hline Angling Pressure & Fish & dimensionless & $\begin{array}{l}\text { rare, occasional, } \\
\text { frequent }\end{array}$ \\
\hline Site Access* & Access & dimensionless & $\begin{array}{l}\text { highway, paved } \\
\text { road, gravel } \\
\text { road, marked } \\
\text { trail or } \\
\text { unmarked trail. }\end{array}$ \\
\hline
\end{tabular}

Note: '*'indicates variables that were used in model selection. All others were correlated to a 
566

567

568

569

570
Table 2. Summary of a priori candidate models used to evaluate relationships between the occurrence of $D$. geminata cells and blooms and environmental variables, including metrics of anthropogenic activity in the Canadian Rocky Mountains. $\mathrm{K}$ is the number of independent variables.

\begin{tabular}{llc}
\hline Model & Variables & K \\
\hline Regional Variables & & \\
$\mathbf{1}$ & Lat + Order + Access & 3 \\
$\mathbf{2}$ & Lat + Order & 2
\end{tabular}

\section{Local Variables}

3

4

5

6

Regional + Local Variables

7

8

9

10 $\begin{array}{ll}\text { Velocity }+ \text { TP }+ \text { TN }+ \text { Temp } & 4 \\ \text { TP }+ \text { TN } & 2 \\ \text { Velocity }+ \text { Temp } & 2 \\ \text { Velocity }+ \text { TP } & 2\end{array}$

(n)

Access + Velocity + TP 3

Lat + Velocity $+\mathrm{TP}$

Lat + Velocity + TP + TN 4

Order + Velocity + Temp + 4

TP 
582 Table 3. A summary of the three most parsimonious General Linear Models for presence or

583

584

585

586 absence of D. geminata cells and blooms and the three most parsimonious General Linear Models for D. geminata cells and amount of AFDM. Model numbers refer to the models outlined in Table 2.

\begin{tabular}{|c|c|c|c|c|c|c|}
\hline Model & Variable & Coefficient & $\mathrm{SE}$ & $\mathrm{AIC}_{\mathrm{c}}$ & $\Delta_{i}$ & $w_{i}$ \\
\hline \multicolumn{7}{|c|}{ Presence or Absence of D. geminata cells } \\
\hline \multirow[t]{5}{*}{10} & Intercept & -1.66 & 2.37 & \multirow[t]{5}{*}{35.94} & \multirow[t]{5}{*}{0} & \multirow[t]{5}{*}{0.92} \\
\hline & Order & 0.49 & 0.45 & & & \\
\hline & Velocity & 2.053 & 1.91 & & & \\
\hline & Temperature & 0.032 & 0.20 & & & \\
\hline & $\mathrm{TP}$ & 54.60 & 65.03 & & & \\
\hline \multirow[t]{3}{*}{6} & Intercept & 1.041 & 0.90 & \multirow[t]{3}{*}{41.36} & \multirow[t]{3}{*}{5.42} & \multirow[t]{3}{*}{0.061} \\
\hline & Velocity & 0.96 & 1.43 & & & \\
\hline & $\mathrm{TP}$ & 22.25 & 63.70 & & & \\
\hline \multirow[t]{5}{*}{3} & Intercept & -0.23 & 1.74 & \multirow[t]{5}{*}{43.52} & \multirow[t]{5}{*}{7.59} & \multirow[t]{5}{*}{0.021} \\
\hline & Velocity & 1.31 & 1.60 & & & \\
\hline & $\mathrm{TP}$ & 11.36 & 72.15 & & & \\
\hline & $\mathrm{TN}$ & 6.98 & 10.35 & & & \\
\hline & Temperature & 0.066 & 0.18 & & & \\
\hline \multicolumn{7}{|c|}{ Abundance of $D$. geminata cells $\left(\right.$ cells $\left./ \mathrm{cm}^{2}\right)$} \\
\hline \multirow[t]{4}{*}{10} & Intercept & $15.85 * * *$ & 1.80 & \multirow[t]{4}{*}{354.99} & \multirow[t]{4}{*}{0} & \multirow[t]{4}{*}{1.00} \\
\hline & Order & $-1.71 * * *$ & 0.32 & & & \\
\hline & Velocity & $-2.14^{*}$ & 0.98 & & & \\
\hline & Temperature & 0.081 & 0.13 & & & \\
\hline \multirow[t]{6}{*}{3} & TP & $-273.96 * * *$ & 41.47 & \multirow[t]{6}{*}{496.09} & \multirow[t]{6}{*}{141.10} & \multirow[t]{6}{*}{$2.29 \times 10^{-31}$} \\
\hline & Intercept & $12.48 * * *$ & 1.53 & & & \\
\hline & Velocity & $-3.31 * *$ & 1.08 & & & \\
\hline & $\mathrm{TP}$ & $-170.98 * * *$ & 44.88 & & & \\
\hline & $\mathrm{TN}$ & -11.58 & 7.37 & & & \\
\hline & Temperature & 0.014 & 0.15 & & & \\
\hline \multirow[t]{3}{*}{6} & Intercept & $11.14 * * *$ & 0.72 & \multirow[t]{3}{*}{547.88} & \multirow[t]{3}{*}{192.89} & \multirow[t]{3}{*}{$1.30 \times 10^{-42}$} \\
\hline & Velocity & -2.27 & 0.97 & & & \\
\hline & $\mathrm{TP}$ & $-202.93 * * *$ & 40.69 & & & \\
\hline
\end{tabular}


Presence or Absence of D. geminata blooms

$\begin{array}{lllllll}10 & \text { Intercept } & 3.47 & 2.68 & 31.36 & 0 & 1.00 \\ & \text { Order } & -0.60 & 0.44 & & & \\ \text { Velocity } & -0.85 & 1.93 & & & \\ & \text { Temperature } & 0.14 & 0.21 & & & \\ & \text { TP } & -416.38 & 267.37 & & & \\ & \text { Intercept } & 0.42 & 1.63 & 47.36 & 16.00 & 0.00034 \\ & \text { Velocity } & 0.19 & 1.30 & & & \\ \text { TP } & -113.78 & 143.93 & & & \\ & \text { TN } & -8.60 & 9.18 & & & \\ & \text { Temperature } & 0.030 & 0.16 & & & \\ & \text { Intercept } & 0.23 & 0.91 & 47.66 & 16.30 & 0.00029 \\ & \text { Velocity } & -0.048 & 1.11 & & & \end{array}$

Amount of $\log \left(\operatorname{AFDM}\left(\mathrm{mg} / \mathrm{cm}^{2}\right)+1\right)$

\begin{tabular}{lllllll}
10 & Intercept & $4.64 * * *$ & 0.79 & 61.90 & 0 & 1.00 \\
& Order & -0.24 & 0.14 & & & \\
Velocity & $-0.78 \sim$ & 0.41 & & & \\
& Temp & $-0.14 *$ & 0.058 & & & \\
& TP & -18.91 & 16.21 & & & \\
& Intercept & $3.60^{* * *}$ & 0.60 & 84.037 & 22.14 & $1.56 \times 10^{-5}$ \\
& Velocity & $-0.83 \sim$ & 0.41 & & & \\
& TP & -7.21 & 16.59 & & & \\
& TN & 1.14 & 2.84 & & & \\
& Temperature & -0.13 & $0.58^{*}$ & & & \\
& Intercept & $2.51 * * *$ & 0.32 & 100.78 & 38.89 & $3.60 \times 10^{-9}$ \\
& Velocity & -0.53 & 0.43 & & & \\
TP & -0.91 & 17.3 & & & \\
\hline
\end{tabular}

587 Note: * indicate significant deviations from the null model. ' $\sim$ ' is a p-value of $<0.1$, ' ${ }^{*}$ ' is a $p$ 588 value of $<0.05$, '**' is a $p$-value of $<0.01$ and ' $* * *$ ' is a $p$-value of $<0.0001 . \Delta_{i}$ is the change in $589 \quad \mathrm{AIC}_{\mathrm{c}}$ scores from the lowest $\mathrm{AIC}_{\mathrm{c}}$ score and $\mathrm{w}_{\mathrm{i}}$ are the $\mathrm{AIC}_{\mathrm{c}}$ weights. 
593

594

595

596

597

598

599

600

601

602

603

604

605

606

607

608

609

610

611

612

613

614

615

\section{List of Figures}

Figure 1. Location of 76 sites within the Canadian Rocky mountains sampled during summer, 2009 , to determine distribution and abundance of $D$. geminata. Black circles indicate blooms, hatched circles indicate that cells were present but blooms were absent, and open circles indicate that no cells were detected. Glacier National Park is in British Columbia and part of the Banff-Yoho-Kootany map. Note the change of scale between Waterton Lakes (bottom left), Jasper (top right) and the remaining National Parks. Arrows indicate the direction of water flow. All maps are oriented in the same direction. Some tributaries have been omitted for clarity.

Figure 2. Mean D. geminata cell abundance $\left(\right.$ Number $\left./ \mathrm{cm}^{2}\right)$ in $1^{\text {st }}$ to $6^{\text {th }}$ order rivers in Alberta and British Columbia Rocky Mountain National Park streams at all sites, sampled during summer, 2009. Error bars represent 95\% confidence intervals.

Figure 3. Relationship between mean density of $D$. geminata cells $\left(\right.$ Number $\left./ \mathrm{cm}^{2}\right)$ and mean concentration of total phosphorus ( $\mu \mathrm{g} / \mathrm{L})$. Solid circles $(\mathrm{A})$ indicate sites with D. geminata blooms and open squares (B) indicate sites with D. geminata cells present but no blooms.

Figure 4. Relationship between ash-free dry mass $\left(\mathrm{mg} / \mathrm{cm}^{2}\right)$ and temperature $\left({ }^{\circ} \mathrm{C}\right)$ for 76 sites sampled during summer, 2009, in Alberta and British Columbia Rocky Mountain National Parks. Solid circles (A) indicate sites with D. geminata blooms and open squares (B) indicate sites with $D$. geminata cells present, but no blooms. Lines represent the best fit from linear regressions with the test statistics presented in the text. 
Jackson, Corbett \& Scrimgeour, Figure 1

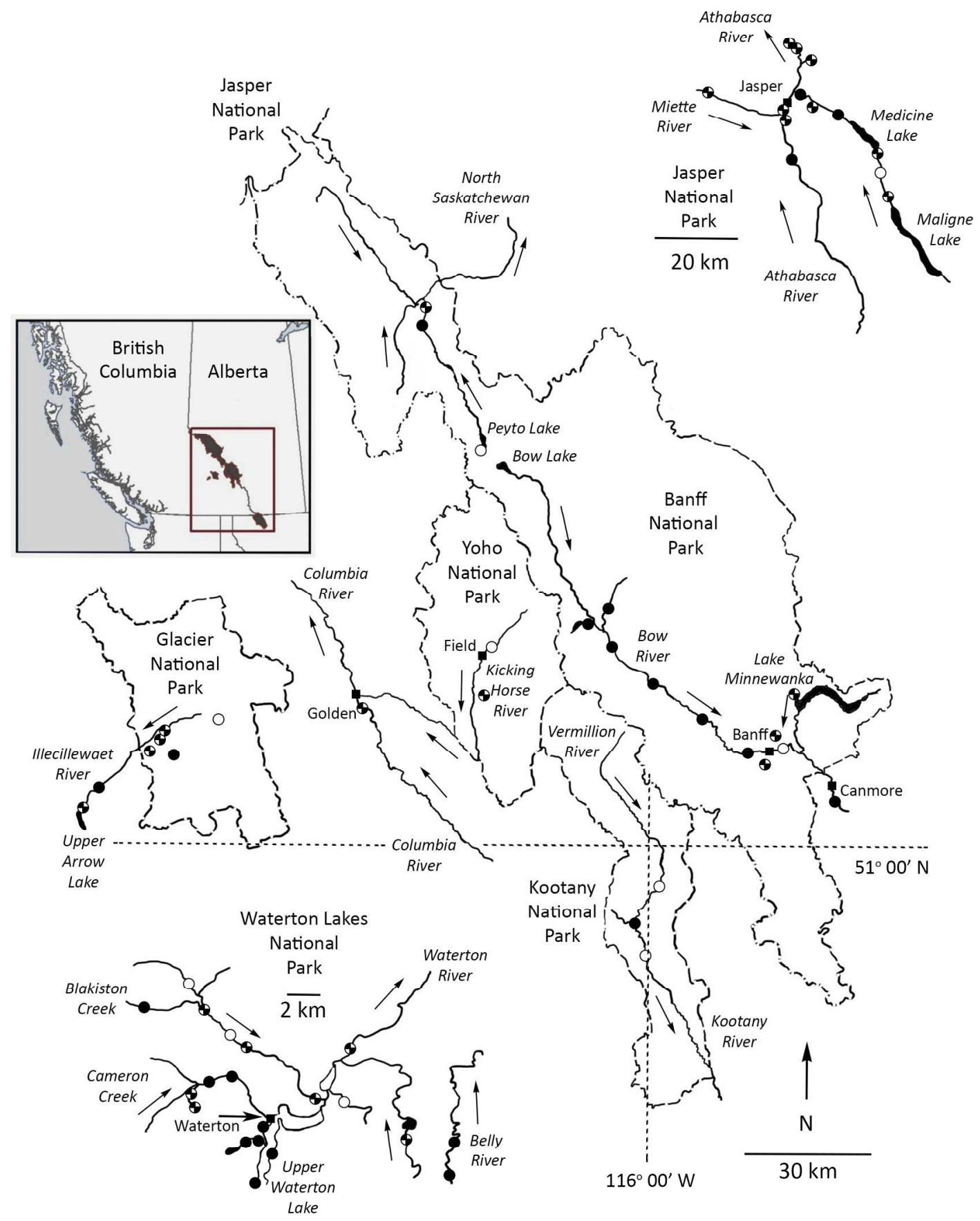


Jackson, Corbett \& Scrimgeour, Figure 2

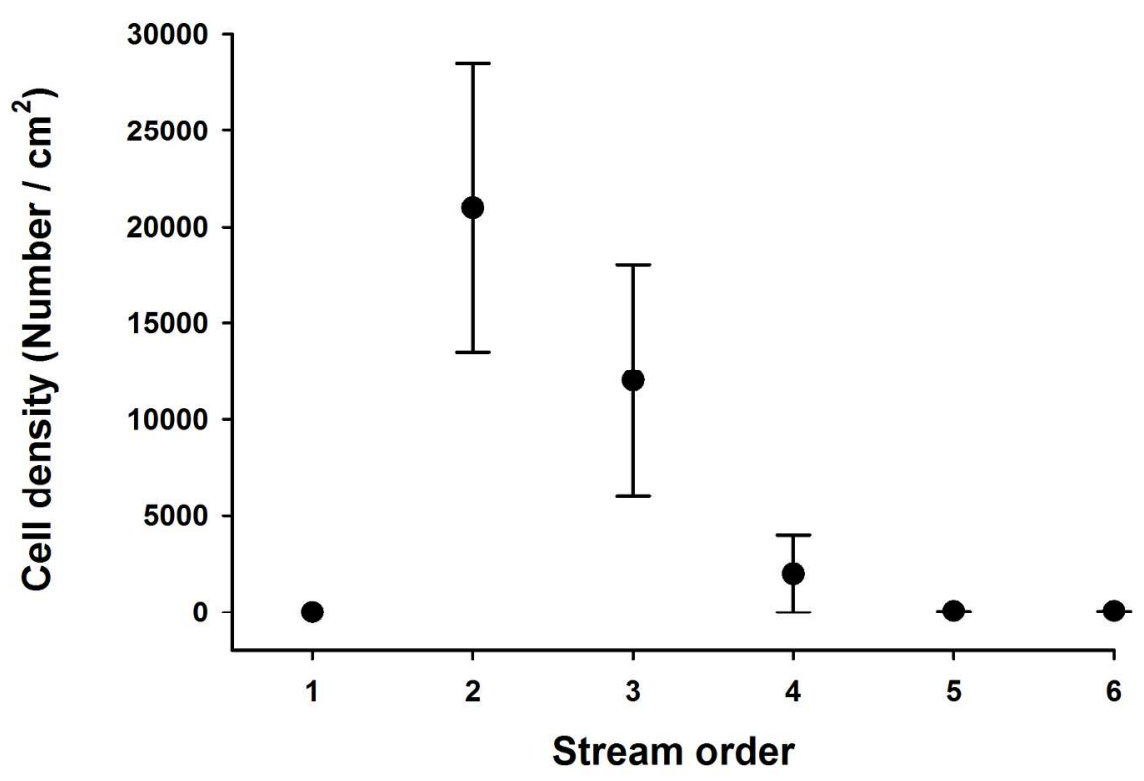


Jackson, Corbett \& Scrimgeour, Figure 3
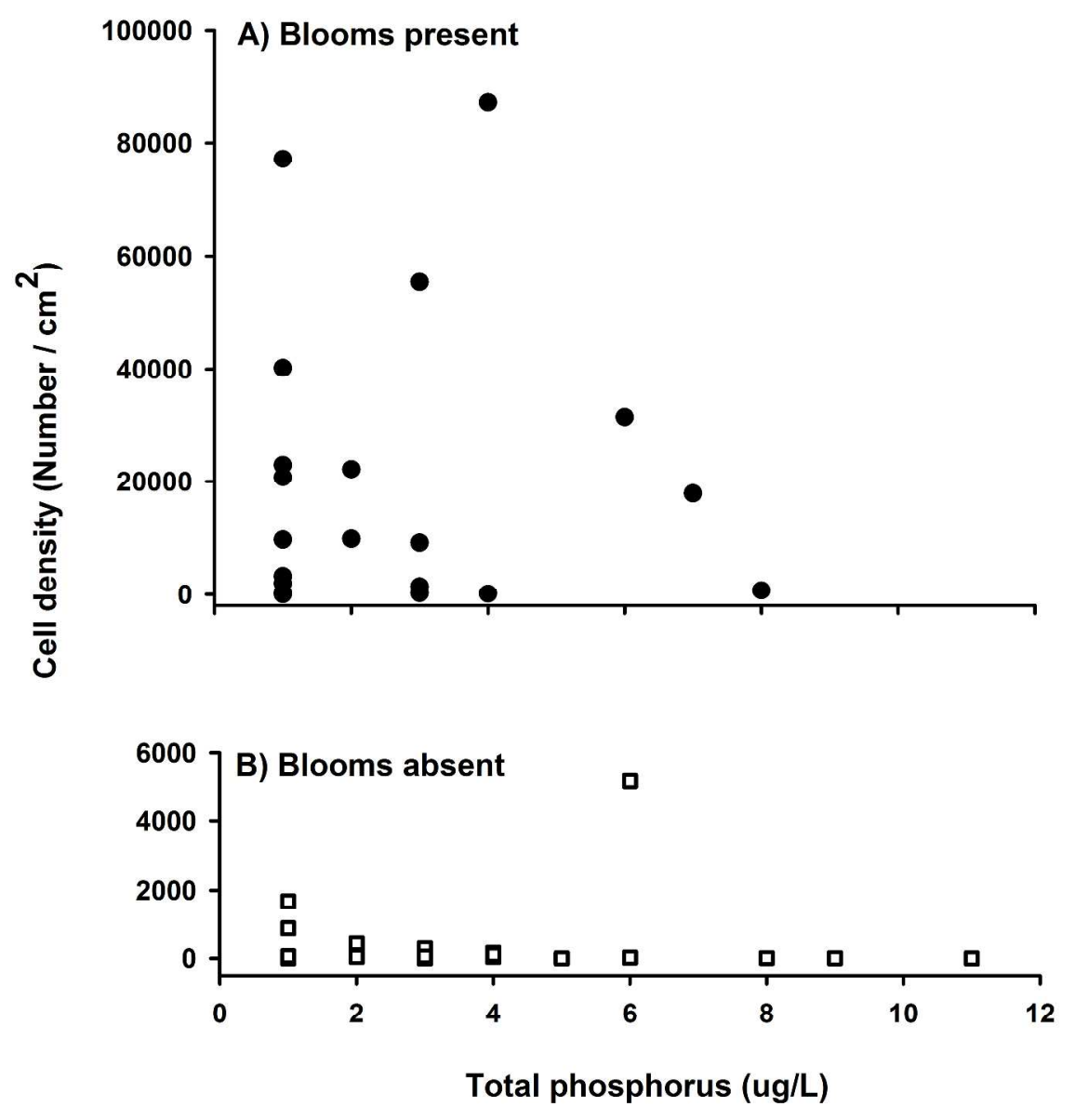
Jackson, Corbett \& Scrimgeour, Figure 4

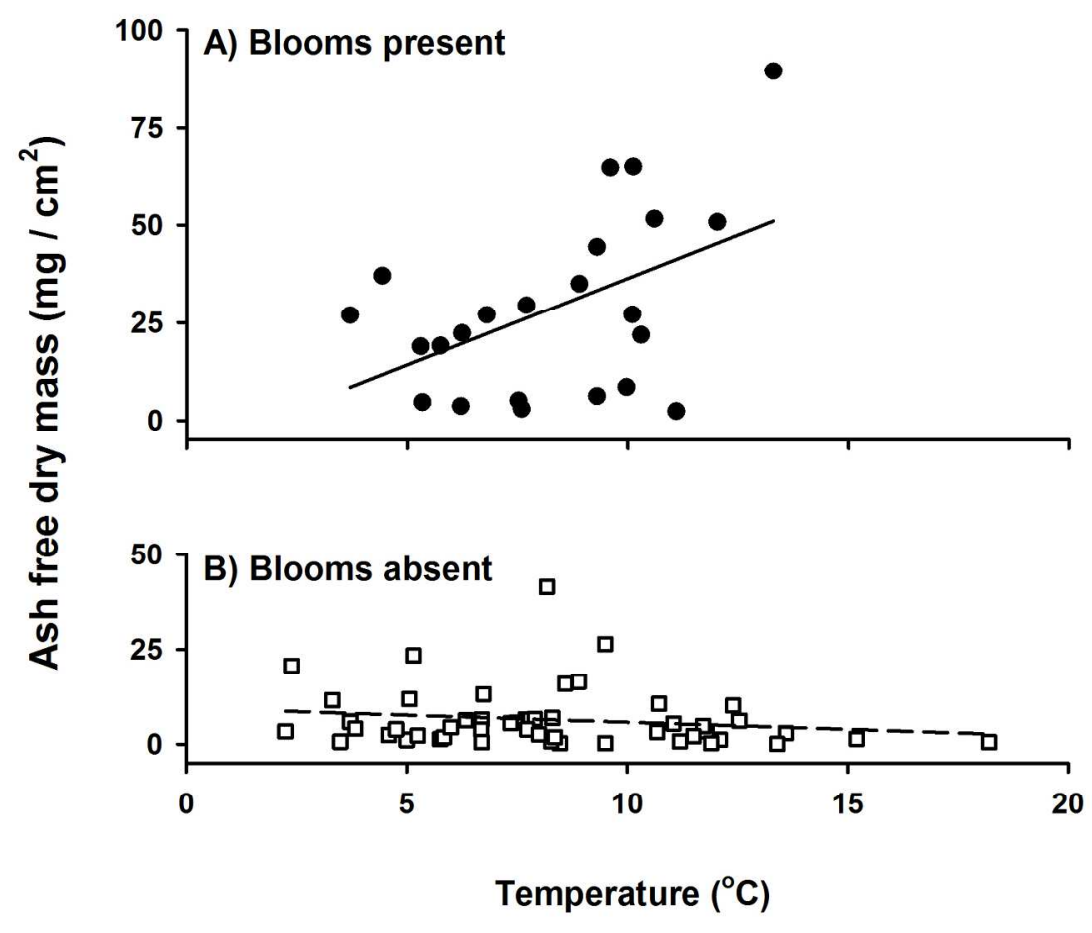




\section{Biosketches}

Leland Jackson is a professor in the Department of Biological Sciences at University of Calgary. His research focuses on relationships ecosystem structure and function and contaminant impacts on aquatic food webs.

Lisa Corbett is involved with program development and implementation with the Glenbow Ranch Provincial Park Foundation and the Weaselhead Park Preservation Society.

Garry Scrimgeour is a senior scientist with Parks Canada Agency. His work focuses on environmental assessments, restoration and monitoring of surface waters in National Parks.

Author Contributions: LJ and GS conceived of the initial idea. GS coordinated access to National Park sites, arranged nutrient analyses and acquired funding. LJ and LC wrote the manuscript. LC helped collect samples, conducted laboratory analyses for cell density, chlorophyll and AFDM and conducted statistical analyses. 